Ks. Jan Lach, Lublin

\title{
UCZTA ZRZESEENIA Z QUMRAN A OSTATNIA WIECZERZA
}

Sekta Sadokitów ${ }^{1}$ ), o której istnieniu dowiedzieliśmy siẹ przed kilku laty z odkrytych dokumentów nad Morzem Martwym miała charakter monastyczny. Wspólne mieszkanie ${ }^{2}$ ), wspólne posiłki, poddanie się dobrowolne władzy zwierzchniei Zrzeszenia, nowicjat, cel, jaki Zrzeszeniu przyświecał - dążenie do doskonałości, wskazuja na wyraźne cechy życia zakonnego ${ }^{3}$ ). Specyficzny stosunek do świątyni jerozolimskiej, jej kapłanów, ofiar, odrębna egzegeza ksiąg świętych, stanowią o nastawieniu sekciarskim ludzi, ktćrzy do Zrzeszenia należeli ${ }^{4}$ ).

1) Nazira ta nie jest przyjmowana powszechnie. Spór, czy sekta była sektą Esseńczyków (por. A. Dupont-Sommer, Obserwations sur le Manuel de discipline decouvert près de la Mer Morte, Paris 1951, lub tenże, Apercus préliminaires sur les manuscrits de la Mer Morte, Paris 1950, 105-117; J. T. Mi1 ik, Dix ans de découvertes dans le Désert de Juda, Paris 1957, 103-112), czy tylko jej odłamem (por. G. Molin, Die Soehne des Lichtes, Wien - Muenchen, 1954, 206-221, lub R. E. MI u p hy, The Dead Sea Scroll and the Bible, Westminster - Maryland, (USA) 1956, 108), czy wreszcie ugrupowaniem całkowicie odrębnym (por. E. D ą browski, Glossy i odkrycia biblijne, Warszawa 1954, 19, lub tenże, Odkrycia nad Morzem Martwym po dziesięciu latach, art. Ruch Biblijny i Liturgiczny, 10 (1957) 373; podobne zapatrywanie na tę kwestię zđaje się mieć R. P. Barthélemy, por. J. Coppens, Chronica, Ephemerides Theologicae Lovanienses 33 (1957) 807).

2) G. Vermè s, Les manuscrits du Désert de Juda, Paris - Tournai $1954,39-44$.

$\left.{ }^{3}\right)$ G. V e r mè s, dz. cyt. 40.

4) 'J. Carmi'gn, L'Utilité ou l'unutilité des sacrifices sanglants dans 
Pewne podobieństwo literatury qumrańskiej do pism Nowego Testamentu dało powód do najróżnorodniejszych hipotez idących aż tak daleko, iż Chrystusa utożsamiano z Mistrzem Sprawiedliwości ${ }^{5}$ ), organizację Zrzeszenia przeniesiono do hierarchicznej organizacji Kościoła ${ }^{6}$ ) odkryto podobieństwo w pojęciach użytych przez pisarzy Zrzeszenia i autorów pism Nowego Testamentu ${ }^{7}$ ); podobieństw tych doszukano się nawet w całych zdaniach ${ }^{8}$ ).

Problemem szczegółowym, który interesuje egzegezę Nowego Testamentu jest uczta wielkoczwartkowa Chrystusa i jej stosunek do uczty sekty Sadokitów. Należy się nim zając tym bardziej, że nie brak głosów dopatrujących się w tym wględzie wielkiego podobieństwa, a nawet tożsamości ${ }^{9}$ ).

A. Opis uczty zrzeszenia znajduje się $w$ dwu znalezionych dotąd dokumentach: Manuale Disciplinae (1Q S) 6, 2-6, oraz w Regula Congregationis (1Q Sa) 2, 13-22. Oto opis uczty w Manuale Disciplinae 6, 2-6:

....Tak zaś niechaj postępują we wszystkich mieszkaniach swoich. Gdziekolwiek ktoś mieszka jeden (dosłownie: jedna) z drugim, niech będzie posłuszny mniejszy więlkszemu co do pracy i pieniędzy. Społem niech także jedzą i społem się modlą i społem obradują. A gdziekolwiek znajdzie się dziesięciu ludzi ze zgromadzenia społeczności, niechaj im nie braknie męża kapłana. Niechaj też siedzą przed nim, każdy na swoim określonym miejscu i $\mathrm{w}$ tym samym (porządku) niech proszą o radę

la "Regle de Communauté de Qumran", Revue Biblique 63 (1956) $524-532$.

5) A. Dupont-Sommer, Apercus préliminaires..., d. c. s. 121.

$\left.{ }^{6}\right)$ E. Johns on, The Dead Sea Manuel of Disciplin and the Jerusalem Church of Act, art. Zeitschrift für die alttestamentliche Wissenschaft 66 (1954) 106-120.

7) K. G. Kuhn, Die in Palaestina gefundenen hebraeischen Texte und das Neue Testament, art. Zeitschrift fuer Theologie und Kirche 47 (1950) 209-211.

8) Por, G. Molin, d. c. tabela I.

${ }^{9}$ ) A. Dupont-Sommer, Aperçus... d. c. 121; J. Danielou, La communauté de Qumran et l'organisation de l'Eglise ancienne, art. La Bible et l'Orient, Paris 1955, 107. K. G. K u h n, Ueber den urspruenglichen Sinn des Abendmahls und sein Verhaeltnis zu den Gemeinschaftsmahlen der Sektenschrift, art. Evangelische Theologie 10 (1951) 519-523. 
w każdej sprawie. Następnie, kiedy przygotują potrawy do jedzenia i moszcz do picia, kapłan podniesie ręke swoją, aby błogosławić pierwociny chleba, albo jeśli moszcz pić będą, kapłan podniesie pierwszy rękę swoją, aby błogosławić pierwociny chleba i moszcz. Niechaj też nie braknie w miejscu, gdzie jest dziesięciu, męża studiującego Prawo dniem i nocą ciągle, dla wzajemnego pożytku".

Opis zaś uczty w Regula Congregationis 2, 16-22 brzmi następująco:

"I wszyscy zwierzchnicy zrzeszenia wraz z mędrcami świętego zrzeszenia siedzieć będą wraz z nimi wedlug swego porządku. A kiedy zbiorą się przy wspólnym stole, lub w celu wypicia moszczu, oraz gdy przygotowany zostanie wspólny stół i zmieszany będzie moszcz (przeznaczony) do picia, niechaj nikt nie wyciąga reki swej nad pierwocinami chleba i moszczu przed kapłanem, gdyż ten błogosławić bedzie pierwszy pierwociny chleba i moszczu i wyciągnie rękę swą. A potem błogosławić będzie chleb Mesjasz Izraela, a następnie wszyscy członkowie zrzeszenia wspólnie, każdy według swej godności. I czynic tak będą według przykazania nad wszystkim przygotowanym pożywieniem, gdy zejdzie sie przynajmniej dziesięciu mężów“.

Opis uczty Sadokitów pozwala na jej rekonstrukcję, choć niezbyt dokładną.

W uczcie uczestniczyli czlonkowie Zrzeszenia. Trudno odpowiedzieć, czy to była uczta dla wszystkich członków, czy tylko dla pewnej grupy. Monastyczny charakter Zrzeszenia wskazuje raczej, że do stoîu zasiadali wszyscy, nawet nowiejusze, po pierwszym roku próby ${ }^{10}$ ). Zanim zasiedli do stołu biesiadnego, wszyscy musieli poddać się obmyciom rytualnym. Nie znany jest nam wygląd stołu biesiadnego, przy którym spożywano potrawy. Był to chyba taki sam stół, jakiego używali powszechnie Hebrajczycy tego okresu ${ }^{11}$ ).

$\mathrm{Na}$ stole leżał chleb, zaś napój (tiroš) mieściły specjalne naczynia. Nie ma wzmianki, z jakiej maki chleb był przygotowany, czy był to chleb przaśny, czy kwaszony. Zależy to od charakteru uczty. Przestrzeganie prawa Mojżeszowego przez

10) Manuale Disciplinae, 5, 15-18; 6, 17.

11) Por. H. Strack, P. Bille rbeck, Kommentar zum Neuen Testament aus Talmud und Midrasch, Muenchen 1928, IV, 617-618. 
Zrzeszenie ${ }^{12}$ ) wskazywałoby raczej, że nie trzeba doszukiwać się czegoś więcej, niż to, co przewidywało prawo. Chleba przaśnego używano do wszystkich ofiar ${ }^{13}$ ), gdyż chleb kwaszony nie mógl być do nich przeznaczony ${ }^{14}$ ); spożywano go w wypadkach nieprzewidzianych ${ }^{15}$ ), w okresie żniw ${ }^{16}$ ), wreszcie w okresie święta Paschy ${ }^{17}$ ). W powszechnym natomiast użyciu był chleb kwaszony, wypiekany z mąlki jęczmiennej ${ }^{18}$ ). gdyż pszenny należał do luksusu ${ }^{19}$ ). W czasie uczty Zrzeszenia używano raczej chleba przaśnego.

Napojem Qumrańczyków w czasie uczty był tiroš. Tym samym wyrażeniem określają ów napój obydwa przytaczane przez nas dokumenty ${ }^{20}$ ). Według W. Geseniusza ${ }^{21}$ ) wyrażenie to $\mathrm{oz}$ nacza moszcz pochodzący $z$ winnych latorośli, ale jeszcze niesfermentowany. Wyrażenie to zostało użyte w Piśmie św. w znaczeniu moszczu winnego ${ }^{22}$ ). $\mathrm{Na}$ określenie wina Pismo św. Starego Testamentu zna inne terminy ${ }^{23}$ ). Mieszanie napoju z wodą świadczy raczej o tym, że ów napój był winem ${ }^{24}$ ). Możliwość pochodzenia moszczu z owoców innej rośliny nie jest wykluczona.

Regula Congregationis pozwala przypuszczać, że w czasie uczty podawane były i inne potrawy $(2,22)$. Wzmianka o błogosławieństwie tych potraw przez kapłanów jest o tyle ważna, gdyż świadczy, że uczta nie zamykała się jedynie w kręgu dwóch elementów (chleb i napój), lecz i innych potraw, co daje

\footnotetext{
12) Por. Manuale 8, 13-16.

$\left.{ }^{13}\right)$ Kapł 2, 4. 11; 7, 12; 8, 2; Liczb 6, 15; Wyjścia 23, 18; 34, 25.

14) Kapl 7, 13. 23.

15) Rodz 18, 6; 19, 3; por. Wyjścia 12, 33 n.

$\left.{ }^{16}\right)$ Rut 2, 14; Test. 12. Patriarchów 5, 11.

$\left.{ }^{17}\right)$ Wyjścia 12, 15-20. 23, 13; 34, 18; Powt. Pr 16, 1-8.

18) Sędz 7, 3; 2 Król 4, 42; Ez 4, 9; Jan 6, 9. 13.

$\left.{ }^{19}\right)$ Por. J. B e hm, artos a. Theol. Woert. z N. T., I, 475 n.

$\left.{ }^{20}\right)$ Man. Disc. 6, 4, 5; Reg. Congr. 2, 17; 18, 20.

21) Hebraeisches und aramaeisches Handwoerterbuch Leipzig 131899
} 888, 1021.

22) Por. Rodz 27, 28; Powt. Pr 33, 28; Joel 2, 19; 2 Król 18, 32; Iz 36, 17.

${ }^{23}$ ) Geseniusz, d. c. 1021 .

24) Reg. Congr. 2, 18. 
możność porównania jej z ucztą żydowską, zwłaszcza o charakterze religijnym ${ }^{25}$ ).

Blogosławieństwo chleba i napoju ${ }^{26}$ ) dokonywane jest przez kapiana, który tę czynność wykonuje z racji swego urzędu. Nie może błogosławić nikt przed nim (IQSa 2, 18, 19), nawet Mesjasz wspominany przez Regula Congr. 2, 20-21. Mesjasz ${ }^{27}$ ) błogosławi pokarmy po benedykcji kapłańskiej. Kolejność taka jest co najmniej zadziwiająca ${ }^{28}$ ). Następnie błogosławią stół z potrawami wszyscy uczestnicy uczty ${ }^{29}$ ). Takie błogosławieństwo czynia nie nad każda potrawa z osobna, lecz nad wszystkimi potrawami znajdującymi sie na stole ${ }^{30}$ ). Przepis ten nie dotyczy jednakże grupy mniejszej niż dziesięciu. Czyżby nie było żadnego błogosławieństwa wtedy, gdy zasiadała do stołu grupa kilku ludzi, np. sześciu, czy ośmiu? Trudno dać na to odpowiedź. Możliwe, że uczty Zgromadzenia w tak małych grupach nie odbywały sie. Wszak chodzi o zrzeszenie o charakterze monastycznym.

$\mathrm{Z}$ danych zawartych $\mathrm{w}$ tekstach relacjonujących o uczcie sekły Sadokitów nie można wyciągać daleko idących wniosków. Autorzy sądzą, że jest w nich mowa o uczcie mesjańskiej, mającej charakter liturgiczny ${ }^{31}$ ). Celem jej jest uzyskanie rytualnej czystości. F. No ets cher ${ }^{32}$ ) dochodzi do takiej konkluzji na podstawie faktu, że nie mogą brać udziału w tej

$\left.{ }^{25}\right)$ H. Strack-P. B ille rbeck, d. c. IV, $617 \mathrm{nn}$.

26) Man. Disc. 6, 6; Reg. Congr. 2, $19-20$.

${ }^{27}$ ) Pomijamy omówienie kwestii, ilu występowało Mesjaszów w czasie uczty. Por. w tej sprawie: K. G. Ku h n, Die beiden Messias Aarons und Israels, art. New Testament Studies 1 (1955) 168-179.

${ }^{28}$ ) Wydawcy Regulae Congregationis, D. Barthélemy i J. T. Milik (Oxford 1955) wyrazili to zdziwienie przez umieszczenie w nawiasie, sic" z wykrzyknikiem.

$\left.{ }^{29}\right)$ Reg. Congr. 2, 21.

30) Reg. Congr. 2, 22.

$\left.{ }^{31}\right)$ R. E. Brown, The Messianism of Qumran, art. The Catholic Biblical Quarterley 19 (1957) 61; The banquet of 1 Q $S$ a 2, 11 was liturgically celebrated with readiness in case God schould bring forth the messiah with them.

32) Zur theologischen Terminologie der Qumran-Texte, Bonn 1956, 190. 
uczcie ani obcy, ani nawet nowicjusze, wypełniający warunki przyjęcia do Zrzeszenia. Jej specyficzny charakter podkreśla również i to, że nawet odbywający już drugi rok próby, dopuszczeni do wspólnego stołu, mający udział w przywilejach Zrzeszenia, wykonywający na równi z pełnymi członkami prace dla dobra wspólnoty, nie mogli pić napoju podanego w czasie uczty ${ }^{33}$ ).

B. Profesor Sorbony Paryskiej A. Dupont Sommer w odczycie, który wygłosił na pierwszym zjeździe orientalistów i archeologów udowadnia ${ }^{34}$ ), że sekta z Qumran jest sektą Esseńczyków. Zdanie to zresztą utrzymuje od początku swych badań nad charakterem zrzeszenia Sadokitów ${ }^{35}$ ). W dowodach swoich powoluje się również na podobieństwo między opisem uczty qumrańskiej i uczty Esseńczyków. Oto jak opisuje ucztє̨ Esseńczyków J. Flawiusz w dziele: De bello Judaico, II 8, 5:

„Napracowawszy się pilnie do godziny piątej (tj. jedenastej przed południem - uwaga tłumacza $\left.{ }^{36}\right)$, znowu zbierają się w oznaczonym miejscu i przepasawszy się lnianą chustą zmywają ciało zimną wodą; dokonawszy tego oczyszczenia, udają się do własnego domu, którego progu nikt nie może przestąpić, kto do sekty nie należy i oto oczyszczeni wkraczają do stołowni, niby do świątyni. Tu siadają $w$ milczeniu, piekarz. przy każdym kładzie koleja chleb, a kucharz stawia naczynia z jedna jedyną potrawą. Przed rozpoczęciem uczty kapłan odmawia modlitwe a do jej skończenia nikt nie śmie dotknąć jedzenia. Po uczcie znowu odmawiają modlitwę; przeto przed i po jedzeniu wielbia Boga jalko rozdawcę życia. Następnie składają szaty swoje, niemal za święte uważane, i znowu rozchodzą się do pracy, którą zajmują się aż do zmierzchu. Potem zbierają się na wspólną wieczerzę, która odbywa się w ten sam sposób. Jeżeli mają wśród siebie gości, to ci także biora udział w biesiadzie. Nigdy ścian tych nie znieważy jakiś hałas, lub bodaj gwar, gdyż nigdy jeden drugiemu nie przerwie $w$ rozmowie. Panujące dokola milczenie wywiera na ludzi z zewnątrz domu będących wrażenie, że tam się odbywa

${ }^{33}$ ) Man, Disc. 6, 20. Por. też G. Vermé s, Les Manuscrits du Desert de. Juda, Paris-Tournai 1954, 42.

$\left.{ }^{34}\right)$ La probleme des influences étrangéres sur la secte juive de Qumran, art. w: Bible et l'Orient, Paris 1955, 75-93.

${ }^{35}$ ) Por. Aperçus préliminaires..., d. c. 105-117; oraz Observations..., d. c. 31 .

36) Tłumaczenie A. Niemojewskiego, Drieje Wojny Żydowskiej, Kraków-Warszawa 1906, 141-142. 
jakieś tajemnicze misterium, wszelako powodem owej ciszy jest niezwykłe umiarkowanie tych ludzi, którzy o tyle używają jadła i napoju, o ile trzeba w ogóle zaspokoić głód i pragnienie“.

Porównanie powyższego opisu uczty Esseńczyków z opisem, znajdującym się w dokumentach qumrańskich wykazuje wiele podobieństw. Zestawia je $\mathrm{K}$. G. $\mathrm{Kuhn}{ }^{37}$ ) w następujący sposób:

1. Uczta jest wspólna dla wszystkich członków.

2. Uczta ma charakter kultowy. Taki charakter nadaja jej modlitwy i oficjalne zebranie Zrzeszenia.

3. Siedzący na przedzie kapłan odmawia modlitwy ${ }^{38}$ ).

4. Przepis uporządkowanego toku rozmowy.

5. Uprzywilejowane miejsce chleba.

Brak podobieństwa $\mathrm{w}$ tym, o czym wspomina Manuale i Regula Congr. iż odmawiane było błogosławieństwo nad chlebem i winem, a nie tylko nad chlebem, jak to było w zwyczaju Esseńczyków nie nastręcza K. G. 'K u h n o w i trudności. Każdą bowiem ucztę źydowska poprzedza błogosławieństwo chleba, a kończy błogosławieństwo wina ${ }^{39}$ ).

C. Pomijając nierozwiązaną kwestię, czy zrzeszenie Qumrańczyków i Esseńczyków należy traktować oddzielnie, czy uważać obydwa te zrzeszenia za jedno i to samo, a więc, czy opisy uczty qumrańskiej nie są niczym innym, jak tylko opisem uczty Esseńczyków, lub odwrotnie, z kolei należy zając stanowisko wobec poglądów dopatrujących się wielkiego podobieństwa ${ }^{40}$ ) uczty Chrystusa w wieczerniku, a nawet jej tożsamości ${ }^{41}$ ) z ucztą qumrańską.

Rzeczywiście zachowanie się Chrystusa w czasie Ostatniej Wieczerzy przypomina zachowanie się kapłana podczas uczty zrzeszenia Qumrańczyków. Czynności jednak Chrystusa, jak

$\left.{ }^{37}\right)$ Ueber den urspruenglichen Sinn..., a. c. s. 511-512.

${ }^{38}$ ) Por. J. M. B a umgarten, Sacrifice and Worship among the Jewish Sectarians of the Dead Sea (Qumran) Scrolls, a. Harvard.

$\left.{ }^{39}\right)$ Str. Bi11. IV, 621-628.

${ }^{40}$ ) Por. J. D a nielo u, La communaute de Qumran et lorganisation de l'Eglise ancienne, a. c. 107.

${ }^{41}$ ) K. G. Kuh n, Ueber den urspruenglichen Sinn... a. c. $519-523$. 
równiez owych kapłanów znajdują swe podobieństwo w każdej uczcie żydowskiej, w której błogosławiono chleb i wino, odmawiano modiitwy dziękczynne ${ }^{42}$ ).

Ostatnia Wieczerza była uczta paschalną i to obchodzona według przepisów sformułowanych następnie w Misznie ${ }^{43}$ ). Odbycie jej na terenie Jerozolimy, przebywanie w ciągu nocy w obrębie murów miasta, jak również samo jej przygotowanie nie mogło mieć miejsca na terenie gminy qumrańskiej, która nie utrzymywała kontaktów ze świątynią ${ }^{44}$ ), nie składała więc ofiary baranka, nic nam też nie wiadomo, by uczty zrzeszenia odbywały się poza obrębem terenu zamieszkania. Nie jest zreszta pewne, czy uczty qumrańskie miały kiedykolwiek charakter paschalny. Odnalezione kości dają jedynie nikłą podstawę do postawienia hipotezy ${ }^{45}$ ).

Choć w obydwu ucztach stwierdzić można wzmianki o ich charakterze eschatologicznym, to charakter ten ma inne podstawy. Zrzeszenie oczekując nadejścia czasów szczęśliwości i Bożego Królestwa, łączyło swą nadzieję z przyjściem Mesjasza, który będzie sprawcą tej szczęśliwości, analogicznie zresztą do nauki proroków. Chrystus natomiast sam Siebie uważał za Bożego Pomazańca (Nt 16, 20; 26, 64; Mk 8, 29; 14, 61; Łk 9, 20; Jan 1, 41; 4, 26; 7, 26-29), na którego Zrzeszenie dopiero oczekiwało. Królestwo Boże według nauki Zrzeszenia miało być na ziemi, a Chrystus nazwał je "nie z tego świata“ (Jn 18, 36). Eschatologiczna uczta Zrzeszenia miała być tą, w której zasiędzie Mesjasz. Chrystus będąc wśród uczniów mówi natomiast o uczcie niebieskiej. Chrystus dając Siebie na pokarm stał się zadatkiem wiecznej uczty, biesiada Zrzeszenia była tylko wstępem do mającej kiedyś nastąpić uczty mesjańskiej $\left.{ }^{46}\right)$.

A już stanowczo nie można znaleźć żadnej paraleli między

${ }^{42}$ ) Por. Str. - Bi11. IV, 621-631 passim.

$\left.{ }^{43}\right)$ Por. Pesachim 10, 1-9.

${ }^{44)}$ Por. G. Moli n, d. c. 185.

${ }^{\left.{ }^{5}\right)}$ J. Starcky, Christianisme et essenisme, a. Bible et Terre sainte 1 (1957) 22.

$\left.{ }^{46}\right)$ Por. J. Starcky, a. c. s. 22. 
obydwoma ucztami dlatego, że słowa błogosławieństwa wypowiedziane przez Chrystusa nad chlebem i winem, stanowiące o możliwości zaistnienia prawdziwej i czystej ofiary zapowiedzianej przez Malachiasza $(1,11)$ zmienily istotę chleba i wina ${ }^{47}$ ). Prawda o transsubstancjacii nie miała żadnego precedensu w uczcie qumrańskiej. Jest to różnica najistotniejsza, którą muszą uznać wszyscy, którzy przyjmuja dosłowną interpretacje siów "to jest Ciato Moje, to jest kielich Krwi Mojej". Uznać więc trzeba za słuszną odpowiedź, jaką W. Marxsen dał $K$. G. Ku h nowi, iż nie ma najmniejszej racji, by szukać początków Wieczerzy Chrystusa na terenie Qumran. Odmienne zdanie może powstać tylko na gruncie nieuzasadnionego sceptycyzmu:

Ks. JAN ŁACH

${ }^{47}$ Wystarczy przytoczyč tu nawet autora protestanckiego G. Dalmana, Jesus - Jeschua, Leipzig 1922, 146; czy G. Walthera, Jesus, das Passalamm des Neuen Bundes, Guetersloh 1950, 45-46. 